\title{
MONACO RADIOCARBON MEASUREMENTS IV
}

\section{J. THOMMERET and Y. THOMMERET}

Centre Scientifique de Monaco, Monaco

The following list of dates includes most of the samples processed from 1968 to 1972. Proportional counting is used and the counting gas is $\mathrm{CO}_{2}$ at constant filling pressure of $740 \mathrm{mmHg}$ at $22^{\circ} \mathrm{C}$ (Thommeret et al., 1969). Samples are counted at least twice on two different counters and errors quoted are averages of standard deviations obtained on each counting.

In 1970 the installations were entirely rebuilt and 3 quartz-lined proportional counters of $1.2 \mathrm{~L}$ were constructed in the laboratory and are now in use. Counting results are periodically punched on tape and the dates calculated with the help of a small calculator.

\section{ACKNOWLEDGMENTS}

We gratefully acknowledge the help of $\mathrm{J}$. L. Rapaire in setting up the equipment, J. Gatliot for electronics maintenance, Miss G. Hugues for samples preparations, and all submitters who added their comments.

\section{SAMPILE DESCRIPTIONS}

\section{GEOLOGIC SAMPLES}

\section{A. France}

\section{Continental shelf of Roussillon, Pyrénées Orientales}

Between Bear Cape $\left(42^{\circ} 31^{\prime} 00^{\prime \prime} \mathrm{N}\right.$ Lat, $3^{\circ} 08^{\prime} 20^{\prime \prime} \mathrm{E}$ Long) and Leucate Cape $\left(42^{\circ} 55^{\prime} 10^{\prime \prime} \mathrm{N}\right.$ Lat,, $3^{\circ} 03^{\prime} 30^{\prime \prime} \mathrm{E}$ Long), the continental shelf (down to $-120 \mathrm{~m}$ ) is spotted with Quaternary remnants. Some are crowned with large coral concretions that are covered by more recent sediment. Invasion of post-Würm sea shaped marine terraces and deposited layers of sand. Many cores 5 to $10 \mathrm{~m}$ long, coll. from 1965 to 1970 and subm. by A. Monaco, Centre Recherches Séd. Marine, UER Sci., Perpignan, Pyrénćes Orientales.

\section{MC-468. Core CLK 3, 155 to $175 \mathrm{~cm}$}

Shell (Cyprina islandica) 155 to $175 \mathrm{~cm}$ in Core CLK $3\left(42^{\circ} 55^{\prime} 35^{\prime \prime}\right.$ $\mathrm{N}$ Lat, $3^{\circ} 29^{\prime} 00^{\prime \prime}$ E Long), water depth $95 \mathrm{~m}$.

MC-469. Core CLK 3, 330 to $350 \mathrm{~cm}$

Shell (Cyprina islandica) in deepest sandy to gravelly horizon, 330 to $350 \mathrm{~cm}$ in core.

\section{MC-465. Core F 123, 210 to $230 \mathrm{~cm}$}

Mixed marine shells (Cyprina islandica, Turritella, Mytilus sp.) in Core F $123\left(42^{\circ} 35^{\prime} 40^{\prime \prime} \mathrm{N}\right.$ Lat, $3^{\circ} 17^{\prime} 00^{\prime \prime} \mathrm{E}$ Long), 210 to $220 \mathrm{~cm}$ in core, water depth $82 \mathrm{~m}$.

\section{MC.331. Core $S 11,250$ to $300 \mathrm{~cm}$}

Shelly sand, heterogeneous horizon, 250 to $300 \mathrm{~cm}$ in Core $\mathrm{S} 11$ 
$\left(42^{\circ} 41^{\prime} 30^{\prime \prime} \mathrm{N}\right.$ Lat, $3^{\circ} 16^{\prime} 15^{\prime \prime} \mathrm{E}$ Long), water depth $90 \mathrm{~m}$. Comment (A.M.): stratigraphically equivalent to MC-468 and MC-469.

\section{MC-250. Core C 29}

Shell fragments (Chlamys sp.) included in siliceous eolian-sand matrix appearing as pebbles in several levels of Core C. $29\left(42^{\circ} 43^{\prime} 10^{\prime \prime} \mathrm{N}\right.$ Lat, $3^{\circ} 7^{\prime} 35^{\prime \prime}$ E Long) near outcropping rock of littoral zone, water depth $47 \mathrm{~m}$. Comment (A.M.): if the organisms, during their life, became embedded in the sandy matrix, age of gritty sediment agrees with paleogeographic data deduced from cores and seismic records.

\section{MC.467. Core F 129, 510 to $540 \mathrm{~cm}$ \\ $23,800 \pm 1000$}

Mixed marine shells (Venus, Turritella, Mytilus) from whole sandy lower part, 510 to $540 \mathrm{~cm}$ in Core F $129\left(42^{\circ} 31^{\prime} 40^{\prime \prime} \mathrm{N}\right.$ Lat, $3^{\circ} 13^{\prime} 00^{\prime \prime}$ E Long), water depth $78 \mathrm{~m}$. Comment (A.M.): medium- to coarse-grained sand horizon pertains to facies called "offshore sands" or "Würm relict sands."

\section{MC-330. Core $59,50 \mathrm{~cm}$}

$18,300 \pm 750$ 16,350 в.c.

Shelly sand from depth $50 \mathrm{~cm}$ in Core S $9\left(42^{\circ} 40^{\prime} 10^{\prime \prime} \mathrm{N}\right.$ Lat, $3^{\circ}$ $26^{\prime} 40^{\prime \prime}$ E Long), water depth $90 \mathrm{~m}$. Comment (A.M.): dates gravelly sand horizon marking late Würm regression at outer border of Continental slope.

\section{MC-334. Core S 17,400 to $450 \mathrm{~cm}$}

$12,900 \pm 200$ $10,950 \mathrm{B.c.}$

Shelly sand in $450 \mathrm{~cm}$ long Core $\mathrm{S} 17\left(42^{\circ} 36^{\prime} 50^{\prime \prime} \mathrm{N}\right.$ Lat, $3^{\circ} 12^{\prime} 15^{\prime \prime}$ E Long), 400 to $450 \mathrm{~cm}$ in core, water depth $72 \mathrm{~m}$. Comment (A.M.): should date horizon of $-70 \mathrm{~m}$ submarine terrace shaped during postglacial transgression.

\section{MC-335. Core S 19, $850 \mathrm{~cm}$}

$$
10,500 \pm 150
$$

Shelly sand from lower sand horizon in Core $S 19,850 \mathrm{~cm}$ long. (42. $49^{\prime} 30^{\prime \prime} \mathrm{N}$ Lat, $3^{\circ} 12^{\prime} 50^{\prime \prime}$ E Long), water depth $60 \mathrm{~m}$. Comment (A.M.): could be same age as terrace at $-55 \mathrm{~m}$.

\section{MC-466. Core F 128, 860 to $878 \mathrm{~cm}$}

$$
8400 \pm 150
$$

6450 B.c.

Mixed shells (Chlamys, Cardium, Venus) in Core F 128 (all sand) (42. $31^{\prime} 10^{\prime \prime} \mathrm{N}$ Lat, $3^{\circ} 9^{\prime} 00^{\prime \prime}$ E Long), 860 to $878 \mathrm{~cm}$ in core, water depth $40 \mathrm{~m}$. Comment (A.M.): date corresponds to stand of sea level characterized by bulky sand that projects through silt mantle in places (Bear and Leucate Capes).

MC-332. Core S 13, 230 to $300 \mathrm{~cm}$

$6000 \pm 100$ Silty, shelly sand in Core S $13,250 \mathrm{~cm}$ long $\left(42^{\circ} 37^{\prime} 22^{\prime \prime} \mathrm{N}\right.$ Lat, $3^{\circ}$ 
$07^{\prime} 50^{\prime \prime} \mathrm{E}$ Long), 120 to $235 \mathrm{~cm}$ in core, water depth $38 \mathrm{~m}$. Comment (A.M.): Flandrian silty facies.

\section{MC-303. Core C 29, 340 to $350 \mathrm{~cm}$}

$$
1350 \pm 60
$$

Tiny lamellibranch and gasteropod shclls in Core C $29\left(42^{\circ} 43^{\prime} 10^{\prime \prime}\right.$ $\mathrm{N}$ Lat, $3^{\circ} 7^{\prime} 35^{\prime \prime} \mathrm{E}$ Long), 340 to $350 \mathrm{~cm}$ in core, water depth $47 \mathrm{~m}$. Comment (A.M.): possible reworking of sediment in vicinity of Roche Lannier, an outcropping reef.

\section{MC-304. Dredging 5 \\ $\delta \mathbf{C}^{1+\%} \%=+\mathbf{1 3} \pm \mathbf{1 0}$}

Lamellibranchs (Pecten, Anomya) form a dredged superficial deposit (42 $4 \mathrm{I}^{\prime} 40^{\prime \prime} \mathrm{N}$ Lat, $3^{\circ} 7^{\prime} 45^{\prime \prime} \mathrm{E}$ Long), water depth 45m, near Roche Iamier.

General Comment (A.M.): duc to complexity of Quaternary stratigraphy and palcogeography shaped by eustatic sea levels on Roussillon continental shelf, interpretation of dates requires a large set of various analyses (Monaco, 1971; Monaco and Thommeret, 1969; Monaco et al., 1972).

\section{Saint-Nazaire shore-pond sediment series}

Shells from various cores from coastal lake of Saint-Nazaire, coll. and subm. by F. Gadel, Centre Recherches Séd. Marine, UER Sci. Perpignan.

MC-397. Saint-Nazaire 1

$2750 \pm 90$

in a transition shell layer, from depth $295 \mathrm{~cm}$ in Core CM (42 $39^{\prime} 3^{\prime \prime} \mathrm{N}$ Lat, $3^{\circ} 15^{\prime} \mathrm{L}$ Long). Coll. 1967.

MC-396. Saint-Nazaire 2

$4360 \pm 90$

Shells (Cavdium) in a transition shell $\mathbf{2 4 1 0}$ B.C. core as MCi-397.

MC-517. Saint-Nazaire 3

$2870 \pm 90$

\section{Shells (Cardinin) trom clepth 205 to 22 (} N Lat, $3^{\circ} 1^{\prime} 20^{\prime \prime}$ E Long). Coll. 1968.

\section{MC-518. Saint-Nazaire 4}

$4300 \pm 70$

Shells (Candium) from depth 370 to $390 \mathrm{~cm}$ in same core $\mathbf{2 3 5 0}$ B.c.

\section{MC-519. Saint-Nazaire 5}

$3670 \pm 80$ $0^{\prime} 10^{\prime \prime}$ E Long), from depth 186 to $200 \mathrm{~cm}$. Coll. 1967.

\section{MC-417. Saint-Nazaire 6}

$4800 \pm 150$

Marine shells in silty Core $C \mathrm{CK}\left(42^{\circ} 40^{\prime} 40^{\prime \prime} \mathrm{N}\right.$ Lat, $3^{\circ}$ 2850 B.C. depth $50 \mathrm{~cm}$ in core. Coll. 1968. 
General Comment (F.G.): in central part of Saint-Nazaire shore-pond, sedimentation rates in recent layers are from 75 to $80 \mathrm{~cm} / \mathrm{millennium}$ (CH and CK cores) in comparison to 90 to $110 \mathrm{~cm}$ for decper oozes in same cores, suggesting quieter conditions for former deposits. In $\mathrm{N}$ part of lagoon a slower rate $(40 \mathrm{~cm} /$ millennium in Cores $C D$ and $G J)$ was found despite fluvial supplies. This may be explained by temporary summer uncovering periods inducing compaction of dry sediment followed by wind erosion.

\section{Golfe du Lion $\alpha$ core series}

Piston core 19m long, coll. 1969 on continental shelf of Golfe du Lion ( $43^{\circ} 13^{\prime} 25^{\prime \prime} \mathrm{N}$ Lat, $4^{\circ} 10^{\prime} 45^{\prime \prime} \mathrm{E}$ Long), water depth $88 \mathrm{~m}$, by $\mathrm{O}$. V. Terebel for CFP and subm. by F. Gadel.

MC-413. Golfe du Lion $\alpha$ core $7.00 m$

Shells (Turritella) in gray silt at $7.00 \mathrm{~m}$ below surface sediment.

\section{MC-414. Golfe du Lion $\alpha$ core $12.80 \mathrm{~m}$}

$12,240 \pm 180$

Serpulid calcareous tubes at core depth $12.80 \mathrm{~m}$.

\section{MC-415. Golfe du Lion $\alpha$ core $17.50 m$}

Shell fragments at core depth $17.50 \mathrm{~m}$.

General Comment (F.G.): since 12,000 B.P. sedimentation rate in this place is $1 \mathrm{~m} /$ millennium. Before 12,000 B.P., sedimentation rate was 35 to $40 \mathrm{~cm} /$ millennium; but compaction must be considered.

\section{Bages-Sigean shore-pond sediment series}

\section{MC-515. Bages-Sigean E 3}

$$
1250 \pm 70
$$

Mixed marine shells (Rissoa, Lucina, Cardium) from depth 80 to $90 \mathrm{~cm}$ in silt, Sta. E, water depth $\operatorname{lm}\left(43^{\circ} 6^{\prime} 20^{\prime \prime} \mathrm{N}\right.$ Iat, $3^{\circ} 0^{\prime} \mathrm{E}$ Long). Coll. 1968 by G. Cahet, Lab. Arago, Banyuls sur Mer, Pyrćnćes Orientales.

\section{MC-516. Bages-Sigean C 3}

Mixed marine shells (Rissoa, Lucina, Cardium) from depth 80 to $90 \mathrm{~cm}$ in sediment, Sta. C, water depth $2 \mathrm{~m}\left(43^{\circ} 5^{\prime} 25^{\prime \prime} \mathrm{N}\right.$ Lat, $2^{\circ} 59^{\prime} 29^{\prime \prime}$ E Long). Coll. 1968 by G. Cahet.

General Comment (F.G.): sedimentation rate depends on position in lagoon and water depth. Rates near shore at Sta. C, which is influenced by fluvial supplies from the Berre R., are twice as great as in the shallow water of Sta. E.

\section{Continental shelf of Provence}

Between Rhône delta and $S$ shore of Massif des Maures at depths from 200 to $300 \mathrm{~m}$ are found, as fossils, North Atlantic shell species, now 
extinct in the Mediterranean. Cores and dredging from continental slope or from canyon rims yielded shells of these species, subm. 1967 to 1971 by C. Froget, Lab. Gćol. Marine, Univ. Marseille-Luminy (Blanc, Froget, and Gien, 1967).

\section{Provence Core B 11-67 series}

Piston core of silty sand, coll. and subm. 1967, in upper part of continental slope $\left(13^{\circ} 08^{\prime} 40^{\prime \prime} \mathrm{N}\right.$ Lat, $5^{\circ} 25^{\prime} 30^{\prime \prime} \mathrm{E}$ Long) S of Bec de Sormiou, water depth $90 \mathrm{~m}$.

\section{MC-243. Core B 11-67, 210cm}

$13,050 \pm 300$

Shells (Cyprina islandica), $210 \mathrm{~cm}$ in core.

\section{MC-242. Core B 11-67, $250 \mathrm{~cm}$}

Shells (Cyprina islandica), $250 \mathrm{~cm}$ in core.

$12,170 \pm 300$ 10,220 в.c.

Gencral Comment (C.F.): ages do not agree with depth in sediment. Reworking is a possible explanation.

\section{Provence shelf Core series}

Sandy and silty piston core $\left(42^{\circ} 58^{\prime} 49^{\prime \prime} \mathrm{N}\right.$ Lat, $3^{\circ} 58^{\prime} 26^{\prime \prime}$ E Long) in $S$ of delta of Rhone R., water depth $96 \mathrm{~m}$.

MC-356. Provence shelf Core, $90 \mathrm{~cm}$

$$
10,350 \pm 200
$$

Shell (Cyprina islandira), $90 \mathrm{~cm}$ in core.

\section{MC-357. Provence shelf Core, $230 \mathrm{~cm}$}

8400 в.C.

Shcll (Cyprina islandica), $230 \mathrm{~cm}$ in core.

\section{Provence continental shelf dredging series}

\section{MC-348. Dredging $\mathbf{R} 30$}

$12,200 \pm 300$

10,250 в.C.

Shells (Venus casina) dredged Scpt. $1960\left(42^{\circ} 58^{\prime} 10^{\prime \prime} \mathrm{N}\right.$ Lat, $5^{\circ} 42^{\prime}$ $30^{\prime \prime}$ E Long), water depth $250 \mathrm{~m}$, on the $\mathrm{E}$ border of Plateau des Blauquières.

\section{MC-215 A. Dredging $S$ of Bandol, Var}

$13,140 \pm 160$

Shells (Venus casina) dredged Sept. $1966\left(42^{\circ} 58^{\prime} 15^{\prime \prime}\right.$ N Lat, $5^{\circ} 41^{\prime}$ $30^{\prime \prime}$ E Long), water depth ca. $250 \mathrm{~m}$.

\section{MC-245 B. Dredging $S$ of Bandol}

$12,470 \pm 190$

Shells (Glycimeris glycimeris) from same dredging as MC-245.

\section{MC-244. Dredging Cassidaigne, Bouches du 13,095 \pm 300 Rhône \\ 11,145 в.c.}

Shells (Cyprina islandica) dredged Oct. $1967\left(43^{\circ} 07^{\prime} 30^{\prime \prime} \mathrm{N}\right.$ Lat, $5^{\circ}$ $26^{\prime \prime} 10^{\prime \prime} \mathrm{E}$ Long), water depth from 300 to $150 \mathrm{~m}$ on W rim of Canyon de Cassidaigne. 


\section{MC-246 A. Dredging Cassidaigne CF 86}

Shells (Venus casina) dredged April $1967\left(43^{\circ} 05^{\prime} 00^{\prime \prime}\right.$ N Lat, $5^{\circ}$ $3 \mathrm{I}^{\prime} 00^{\prime \prime} \mathrm{E}$ Long), water depth from 250 to $200 \mathrm{~m}$ on E rim of Canyon de Cassidaigne, sample deeply worm-pitted.

MC-246 B. Dredging Cassidaigne CF 86

$6970 \pm 100$

Uncorroded shell (Vemus casina). Comment: no significant age difference between corroded and non-corroded shells.

MC-247. Dredging Cassidaigne CF 16

$9600 \pm 100$ 7650 B.C.

Calcarcous tubes of shell-worm (Ditrupa arictina) dredged ( $13^{\circ} 01^{\prime}$ $15^{\prime \prime} \mathrm{N}$ Lat, $5^{\circ} 30^{\prime} 10^{\prime \prime} \mathrm{E}$ Long), water depth trom $24010220 \mathrm{~m} \mathrm{on} \mathrm{E}$ edge of Canyon de Cassidaigne.

\section{MC-248. Dredging Cassidaigne R 178}

$5600 \pm 100$ 3650 B.c.

Shells of unid. large oysters, supposedly of Tertiary age dredged $1966\left(43^{\circ} 07^{\prime \prime} 30^{\prime \prime} \mathrm{N}\right.$ Lat, $5^{\circ} 29^{\prime} 00^{\prime \prime} \mathrm{E}$ Long), water depth from 600 to $500 \mathrm{~m}$. Comment (C.F.): quoted age is probably correct, though estimated age was much greater. Oysters were attached to sandstone block dated 27,900 в.P. (MC-434).

\section{MC-358. Dredging Cassidaigne F 5}

$10,000 \pm 150$

Shells (Modiolus modiolus) dredged Jan. $1967\left(43^{\circ} 06^{\prime} 10^{\prime \prime} \mathrm{N}\right.$ Lat, $05^{\circ} 27^{\prime} 20^{\prime \prime}$ E Long), water depth from 250 to $150 \mathrm{~m}$, on $\mathrm{W}$ rim of Canyon de Cassidaigne.

MC-359. Dredging Cassidaigne F 4

Shell (Cyprina islandica). Coll. March 1969 in same zone as Dredging F 5, water depth ca. $345 \mathrm{~m}$. Shell all pitted and bored by worms.

MC-360. Dredging Cassidaigne F 3

$11,000 \pm 200$

Shell (Panopea norwegica) dredged Aug. $1967\left(43^{\circ} 05^{\prime} \mathrm{N}\right.$ Lat, $5^{\circ} 30^{\prime}$ $50 "$ E Long), water (lepth from 350 to $150 \mathrm{~m}$.

\section{MC-361. Dredging Cassidaigne F 2}

$9800 \pm 200$

Shell (Buccinum undatum). Coll. March $1968\left(43^{\circ} 06^{\prime} 40^{\prime \prime} \mathrm{N}\right.$ Lat, $5^{\circ} 32^{\prime}$ E Long).

\section{MC-362. Dredging Cassidaigne F $1 \quad \delta C^{L+1 / \%} / \%=+21 \pm 8$}

Shells (V'enus casina) coll. alive May $1969\left(43^{\circ} 07^{\prime} \mathrm{N}\right.$ Lat, $5^{\circ} 32^{\prime}$ $30^{\prime \prime} \mathrm{E}$ Long) in dredging of same zone as $\mathrm{F} 4$ (MC-359) and F 5 (MC-358), water depth ca. $135 \mathrm{~m}$ on $\mathrm{E}$ edge of Canyon de Cassidaigne.

General Comment (C.F.): North Atlantic species of shells cored or dredged in top part of continental slope (Plateau des Blauquières, top of Canyon de Cassidaigne) at depth from 300 to $200 \mathrm{~m}$ and dated as W'ürm 
are also found as shell accumulations, dated from 13,000 to 10,000 B.P., corresponding to milder postglacial climate (Dryas I, Allerod, Dryas II) that induced their extinction. At that time, sea level was $80 \mathrm{~m}$ lower than at present. Some species (Venus casina, Glycimeris glycimeris, Ditrupa arietina), always present in the Mediterranean, survived these climatic changes up to the present, although they are found at unusual depth. l'enus casina, coll. alive is relic of these populations (Froget et al., 1972).

\section{Provence continental shelf Core D 11-67 series}

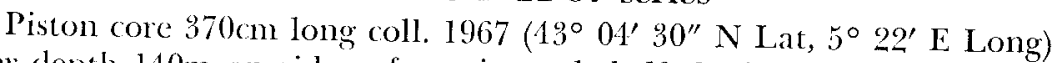
water depth $140 \mathrm{~m}$ on ridge of continental shelf, $\mathrm{S}$ of Marseille, Bouches du Rhone, subm. by C. Froget.

\section{MC-351. Core D 11-67, 0 to $11 \mathrm{~cm}$}

Free calcareous algae.

MC-352. Core D 11-67, 22 to $35 \mathrm{~cm}$

Frce calcareous algae.

MC-439. Core D 11-67, 40 to $50 \mathrm{~cm}$

Calcareous algae.

$16,200 \pm 360$

14,250 в.c.

MC-438. Core D 11-67, 50 to $60 \mathrm{~m}$

Calcareous algae.

$$
16,100 \pm 360
$$

14,150 в.c.

$$
\begin{aligned}
& 19,350 \pm 700 \\
& 17,400 \text { в.с. }
\end{aligned}
$$

MC-437. Core D 11-67, 70 to $80 \mathrm{~cm}$

$27,700 \pm 1500$

25,750 в.C.

Mixed sample of polychaete worm tubes (Salmacina) and bryozoan tubes (Hippodiplosia fascialis $\mathrm{P}$ ).

MC-436. Core D 11-67, 80 to $90 \mathrm{~cm}$

$30,700 \pm 1800$

Coarse calcareous sand, grain-size fraction $>0.5 \mathrm{~mm}$.

MC.435. Core D 11-67, 90 to $100 \mathrm{~cm}$

$30,300 \pm 1800$

Bryozoans.

28,350 в.C.

MC.353. Core D $11.67,120$ to $130 \mathrm{~cm}$

Calcareous sand, grain-size fraction $>2 \mathrm{~mm}$.

$28,000 \pm 1700$

26,050 в.C.

\section{MC-355. Core D 11-67, 340 to $350 \mathrm{~cm}$}

$29,300 \pm 1600$

Bryozoans (Hippodiplosia fascialis).

27,350 в.c.

General Comment (C.F.): dating technique probably reaches its limit at corc depth $\mathrm{Im}$. 'Thus, calculated sedimentation rate is poor and variable: ca. $12 \mathrm{~cm} / 1000$ yr from 0 to $50 \mathrm{~cm}$ and 2 to $3 \mathrm{~cm} / 1000$ yr from 40 to $60 \mathrm{~cm}$. Results agree with pteropod distributions in core: $\mathrm{N}$ Atlantic pteropod (Spiratella retroversa) is only species found at core depths $>40 \mathrm{~cm}$. 
Golfe du Lion Piston Core 9-68 series

Piston core $1850 \mathrm{~cm}$ long, coll. Sept. $1968\left(43^{\circ} 13^{\prime} 25^{\prime \prime}\right.$ N Lat, $4^{\circ} 10^{\prime}$ $45^{\prime \prime}$ E Long), water depth $88 \mathrm{~m}$, ca. $50 \mathrm{~km}$ SE Montpellier. Sandy silt, mostly from Rhône Delta, with shell debris. Subm. 1971 by C. Froget.

\section{MC-428. Core 9.68, $300 \mathrm{~cm}$}

Unid. shell fragments.

MC-429. Core 9-68, $700 \mathrm{~cm}$

Unid. shell fragments.

MC-430. Core 9-68, $1500 \mathrm{~cm}$

Shell fragments (Cyprina islandica).

MC-431. Core $9.68,1700 \mathrm{~cm}$

Shcll fragments (Cyprina islandica).

\section{MC-432. Core 9-68, $1800 \mathrm{~cm}$}

Unid. shell fragments.
$6900 \pm 150$

4950 в.C.

$7700 \pm 140$ 5750 B.c.

$19,000 \pm 250$ 17,050 в.C.

$31,500 \pm 3000$ $\mathbf{2 9 , 5 5 0}$ в.C.

$13,300 \pm 250$

11,350 B.c.

General Comment (C.F.): compared to Core D 11-67, sedimentation rate is much higher $(\mathrm{ca} .1 \mathrm{~m} / 1000 \mathrm{yr}$ ) from 300 to $1500 \mathrm{~cm}$. The $1700 \mathrm{~cm}$ level (MC-431) appears older than surrounding ones: $1500 \mathrm{~cm}(\mathrm{MC}-430)$ and $1800 \mathrm{~cm}$ (MC-432) suggesting reworking. Appearance of $\mathrm{N}$ Atlantic pteropod (Spiratella retroversa), $900 \mathrm{~cm}$, agrees with age in core.

Provence littoral zone consolidated formations

MC-347. Saint-Cyr-les-Lecques, Var

Shells (Patella ferruginea) from fossil beach of cemented sand and pebbles covered by consolidated dune sand formation $\left(\begin{array}{lll}43^{\circ} & 10^{\prime} 20^{\prime \prime} \mathrm{N}\end{array}\right.$ Lat, $5^{\circ} 41^{\prime} 40^{\prime \prime}$ E Long), alt. +3m. Coll. and subm. 1969 by C. Froget.

\section{MC-433. Cavalaire, Var}

$24,400 \pm 1000$

Fragments of dredged shelly sandstone $\left(43^{\circ} 06^{\prime} 30^{\prime \prime} \mathrm{N}\right.$ Lat, $6^{\circ} 33^{\prime}$ $30^{\prime \prime}$ E Long), water depth 220m, S of Cap Cavalaire. Cioll. and subm. 1969 by C. Froget. Comment: dates a submarine lithification.

\section{MC-434. Cassidaigne, Bouches du Rhône}

Unid. shell fragments extracted from dredged sandstone cobbles ( $43^{\circ} 07^{\prime} \mathrm{N}$ Lat, $5^{\circ} 31^{\prime} \mathrm{E}$ Long), water depth from 400 to $350 \mathrm{~m}$, in Canyon de Cassidaigne. Coll. and subm. 1969 by C. Froget. Comment (C.F.): dates a submarine lithification.

MC-349. Isle of Riou 1

$1200 \pm 130$

Calcareous, slightly cemented algae from sea floor, $-18 \mathrm{~m}$, Plateau 
des Chèvres $\left(43^{\circ} 11^{\prime} 10^{\prime \prime} \mathrm{N}\right.$ Lat, $5^{\circ} 24^{\prime} 30^{\prime \prime}$ E Long) near Isle of Riou, Bouches du Rhône. Coll. and subm. 1969 by C. Froget.

MC.350. Isle of Riou 2

Calcareous algae from area of MC-349, water depth $15 \mathrm{~m}$. Coll. and subm. 1969 by C. Froget. Comment (C.F.): dates for submarine rocks (MC-454, -434, -349, -350) vary from 1200 to 27,900 yr B.p. and confirm a submarine medium of consolidation if their present depth is considered. They aid study of diagenesis of carbonaceous sediment in this medium.

\section{Isle of Riou Cardial site series, Bouches du Rhône}

Marine shells from open-air habitat, nearly destroyed by removal of sand from a 19 th century sand pit $\left(43^{\circ} 10^{\prime} 50^{\prime \prime} \mathrm{N}\right.$ Lat, $5^{\circ} 23^{\prime} \mathrm{E}$ Long), alt. ca. $+25 \mathrm{~m}$ in NW Isle of Riou, near Marseille. Rough early cardial pottery and poor lithic industry remains: milling stones cut in Quaternary sandstone blocks not found on island. Coll. and subm. by C. Froget.

\section{MC-440. Isle of Riou Cardial Site 1}

Shells (Patella caerulea).

\section{MC-441. Isle of Riou Cardial Site 2}

Shells (Patella lusitanica).
$7600 \pm 100$

$\mathbf{5 6 5 0}$ в.C.

General Comment (C.F.): dates agree with pottery for early cardial campsite. At that time sea level was ca. $20 \mathrm{~m}$ lower than at present and island was connected to land (Courtin and Froget, 1970).

\section{Cap Ragnon cave, Bouches du Rhône}

Shells from early cardial Neolithic habitat in cave of Cap Ragnon, Le Rove, NW coast, bay of Marseille ( $43^{\circ} 21^{\prime} \mathrm{N}$ Lat, $5^{\circ} 16^{\prime} \mathrm{E}$ Long). Coll. 1970 and subm. 1971 by J. Courtin, CNRS, Marseille.

\section{MC-500 A.}

Shells (Patella caerulea).

\section{MC-500 B.}

Shells (Trococochlea turbinata).

Comment: dates agree with others of cardial site in Ile Riou (MC440: 7600 в.P.; MC-441: 7400 B.P.).

\section{Grotte des Trémies, Cassis, Bouches du Rhône}

L arge submarine cave ( $43^{\circ} 12^{\prime} 12^{\prime \prime} \mathrm{N}$ Lat, $5^{\circ} 30^{\prime} 42^{\prime \prime}$ E Long), at base of overhanging cliff. In midst of cave at $-18 \mathrm{~m}$ a $50 \mathrm{~cm}$ diam. well, cored with a sucking pump in Versilian sediment $5 \mathrm{~m}$ thick, stopped at $-24 \mathrm{~m}$ depth on large blocks and hard cryoclastic sediments of Würm age. Samples coll. and subm. 1970 by E. Bonifay, lab. Géol. Marine, Univ. Marseille-Luminy. 
MC-377 A. Grotte des Trémies, 50 to $100 \mathrm{~cm}$

Coral (Corallium rubuum), 50 to $100 \mathrm{~cm}$ in core.

MC-377 B. Grotte des Trémies, 50 to $100 \mathrm{~cm}$

Opercula of Turbo opercularis.

MC-378 A. Grotte des Trémies, 100 to $150 \mathrm{~cm}$ Coral (Corallium rubrum).

MC-378 B. Grotte des Trémies, 100 to $150 \mathrm{~cm}$ Opercula of Turbo.

MC-379. Grotte des Trémies, 150 to $200 \mathrm{~cm}$ Opercula of Turbo.

MC-380. Grotte des Trémies, 200 to $250 \mathrm{~cm}$ Opercula of Turbo.

MC-381. Grotte des Trémies, 250 to $300 \mathrm{~cm}$ Opercula of Tubo.

MC-382. Grotte des Trémies, 300 to $350 \mathrm{~cm}$ Opercula of Turbo.

MC-383. Grotte des Trémies, 350 to $400 \mathrm{~cm}$ Opercula of Turbo.

MC-384. Grotte des Trémies, 400 to $450 \mathrm{~cm}$ Opercula of Twbo.

MC-385. Grotte des Trémies, 450 to $500 \mathrm{~cm}$
$1290 \pm 90$

A.D. 660

$$
1200 \pm 70
$$

A.D. 750

$$
\begin{gathered}
1980 \pm 90 \\
30 \text { B.c. } \\
2040 \pm 80 \\
90 \text { B.C. } \\
2730 \pm 80 \\
780 \text { B.c. }
\end{gathered}
$$

$4050 \pm 100$ 2100 B.C.

$4760 \pm 100$ 2810 в.с.

$4820 \pm 100$ 2870 B.c.

$5520 \pm 100$ 3570 s.C.

$5720 \pm 100$ 3770 B.C.

$5730 \pm 100$ 3780 B.C.

Opercula of Turbo.

General Comment (E.B., J.T.): in Grotte des Trémies Versilian sedimentation begins ca. 5800 B.P. $(-23 \mathrm{~m})$. First appearance of coral (200 to $250 \mathrm{~cm}$ ) only begins after complete submergence of cave, i.e., $-7 \mathrm{~m}$ sea level ca. 4000 B.P. (MC-380). Reduced sedimentation rate above $-7 \mathrm{~m}$ sea level should indicate a longer stand of sea at that level (Bonifay et al., 1971).

MC-329. Golfe de Frejus, Var

$11,800 \pm 200$

9850 в.C.

Lamellibranch shells (Cardium glaucum) in upper silty sand 43 to

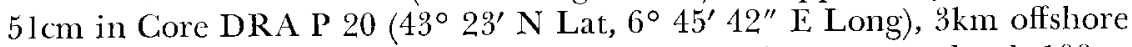
Saint Aygulf, Var. Core from top of continental slope, water depth $100 \mathrm{~m}$. 
Coll. and subm. 1967 by G. Bellaiche, Centre de Recherches Géodynamiques, Villefranche-sur-Mer. Comment (G.B.): silty sand corresponding to an acoustic-reflection layer detected throughout Gulf by "mud penetrator," was deposited, as supposed, at end of Würm IV, more precisely during Dryas (Bellaiche et al., 1969).

\section{MC-314. Saint Tropez, Var}

$11,700 \pm 100$

Shells (Venus casina) from a shelly sand 315 to $320 \mathrm{~cm}$ in Core DRA P 71 (43 $18^{\prime} \mathrm{N}$ Lat, $6^{\circ} 40^{\prime} \mathrm{E}$ Long), water depth $100 \mathrm{~m}$. Coll. and subm. 1967 by G. Bellaiche. Comment (G.B.): structure and age of sandy layer dated in DRA P 20 (MC-329) from lower Argens Valley are very similar to this layer from top of canyon of Saint Tropez (Bellaiche, 1971).

MC-315. Open-sea core DRA P 5

Fraction $>40 \mu$ shelly sand from 610 to $615 \mathrm{~cm}$, in Core CAP P 5 $\left(42^{\circ} 58^{\prime} \mathrm{N}\right.$ Lat, $6^{\circ} 48^{\prime} \mathrm{E}$ Long), water depth $2500 \mathrm{~m}$. Abyssal plain of Isle of Levant. Coll. and subm. 1967 by G. Bellaiche.

\section{Grotte du Corail, Villefranche-sur-Mer}

Grotte du Corail, a submarine cave, $\left(43^{\circ} 41^{\prime} 30^{\prime \prime} \mathrm{N}\right.$ Lat, $7^{\circ} 18^{\prime} 30^{\prime \prime}$ E Long), in bay of Villefranche, Alpes Maritimes, at foot of Mont Boron, opens at ca. $-26 \mathrm{~m}$. Silty sediment of floor of cave, manually cored down to bedrock by divers, yielded many shell remains. Core 69 coll. and subm. 1969; Core 70 coll. and subm. 1970 by H. De Lumley, Fac. Sci., Marseille.

\section{Grotte du Corail Core 69 series}

\section{MC-371. Grotte du Corail C $69,35 \mathrm{~cm}$}

$3150 \pm 80$

Iamellibranch and gastr (absolute level) $22.75 \mathrm{~m}$.

MC-370. Grotte du Corail C 69, $120 \mathrm{~cm}$

Madreporeans, water clepth $23.60 \mathrm{~m}$.

MC-369. Grotte du Corail C 69, $160 \mathrm{~cm}$

Madreporeans, water depth $24 \mathrm{~m}$.

MC-368. Grotte du Corail C $69,200 \mathrm{~cm}$

Lamellibranch shells, water depth $24.40 \mathrm{~m}$.

MC-367. Grotte du Corail, C 69, $250 \mathrm{~cm}$

Lamellibranch shells, water depth $24.90 \mathrm{~m}$.

MC-366. Grotte du Corail C 69, $310 \mathrm{~cm}$

$5040 \pm 100$ 3090 в.c.

$5650 \pm 80$ 3700 в.C.

$5850 \pm 70$ 3900 B.C.

$6100 \pm 100$ 4150 B.c.

$5650 \pm 100$

Lamellibranch and gastropod shells, water depth $25.50 \mathrm{~m}$. Difficulties encountered in coring disturbed the sampling. 


\section{MC-365. Grotte du Corail C $69,350 \mathrm{~cm}$}

Lamellibranch shells, water depth $25.90 \mathrm{~m}$. Same remark as for MG-366.

Grotte du Corail Core 70 series

MC-449. Grotte du Corail C 70, 50cm

$3060 \pm 60$

Opercula of Turbo and lamellibranch shells, depth $50 \mathrm{~cm}$ in core, water depth (absolute level) $21.10 \mathrm{~m}$.

MC-450. Grotte du Corail C 70, $100 \mathrm{~cm}$

$3800 \pm 90$

Opercula of Turbo, water slepth $21.60 \mathrm{~m}$.

MC-452. Grotte du Corail C 70, $150 \mathrm{~cm}$

$4750 \pm 100$

Opercula of Turbo and lamellibranch shells, water depth $22.10 \mathrm{~m}$.

MC-454. Grotte du Corail C 70, 200cm

$4930 \pm 100$

Lamellibranch shells and corals (Corallium rubrum), water depth $22.60 \mathrm{~m}$.

$5670 \pm 110$

MC-456. Grotte du Corail C 70, $250 \mathrm{~cm}$

3720 B.c.

Opercula of Turbo and Arca sp. shells, water depth $23.10 \mathrm{~m}$.

MC-458. Grotte du Corail C 70, $300 \mathrm{~cm}$

$7150 \pm 130$

5200 в.c.

Fraction of shelly sand $>0.75 \mathrm{~mm}$, water depth $23.60 \mathrm{~m}$.

General Comment (H.L.): cave was filled by silty submarine sediment from 6080 (middle Atlantic) to 3060 B.P. (end of Boreal). Results show that sea level was already higher than $-26 \mathrm{~m}$ (floor of cave) ca. 6100 B.P.

Grotte du Mérou, Core M 70 series, Villefranche-sur-Mer

Submarine cave $\left(43^{\circ} 41^{\prime} 30^{\prime \prime} \mathrm{N}\right.$ Lat, $7^{\circ} 19^{\prime} 13^{\prime \prime} \mathrm{E}$ Long) on W cliff of Cap Ferrat in bay of Villefranche. Opening ca. $-26 \mathrm{~m}$. Many similarities with Grotte du Corail in same bay. Sediment Coring M 70 by free divers yielded many shells, subm. 1971 by H. de Lumley.

MC-443. Grotte du Mérou M 70, 70cm

$1900 \pm 70$

Opercula of Turbo, depth $70 \mathrm{~cm}$ in core, water depth $24.80 \mathrm{~m}$.

MC-444. Grotte du Mérou M 70, $100 \mathrm{~cm}$

$3030 \pm 80$

Opercula of Turbo, water depth $25.10 \mathrm{~m}$.

1080 B.C.

MC-446. Grotte du Mérou M 70, 120cm

$5860 \pm 100$

3910 R.C.

Lamellibranch shells and opercula of Turbo, water depth $25.30 \mathrm{~m}$. 


\section{MC-447. Grotte du Mérou M 70, $150 \mathrm{~cm}$}

Iamellibranch and gastropod shells, water depth $25.60 \mathrm{~m}$.

MC-448. Grotte du Mérou M 70, $170 \mathrm{~cm}$

$5320 \pm 110$

Gastropod shells, water depth $25.80 \mathrm{~m}$. 3370 B.c.

General Comment (H.L.): disturbed chronology of sediments probably results from difficulties in manual coring. Chronology of filling similar to Grotte du Corail; same conclusion applies.

\section{Grotte Huet series, Golfe Juan}

Submarine cave opening at $-30 \mathrm{~m}$ on cliff wall of submerged reef le Secanion (49 $32^{\prime} 29^{\prime \prime} \mathrm{N}$ Lat, $7^{\circ} 6^{\prime} 7^{\prime \prime} \mathrm{E}$ Long) offshore Juan les Pins, Alpes Maritimes. At base of cave, $18 \mathrm{~m}$ from entrance, continental deposits hardened in breccia and covered with flowstone dated older to younger Dryas 14,690 B.P. (Ly-403) and 10,500 B.P. (Ly-404) by J. Lin. Free divers manually cored silty marine sediments beneath porch of cave and found many shells; subm. 1972 by H. de Lumley.

\section{MC-535. Grotte Huet 3 C, $50 \mathrm{~cm}$}

$$
2670 \pm 90
$$

Gastropod shells, water depth $27.50 \mathrm{~m}$.

\section{MC-538. Grotte Huet 9 C, $160 \mathrm{~cm}$}

$3810 \pm 70$

Lamellibranch shells and opercula of Tubo, water depth $28.60 \mathrm{~m}$.

\section{MC-539. Grotte Huet 11 C, $200 \mathrm{~cm}$}

$4340 \pm 100$

Lamellibranch shells, water depth $29 \mathrm{~m}$.

\section{0 в.C.}

$4900 \pm 100$

MC-543. Grotte Huet $25 \mathrm{C}, \mathbf{2 7 0 \mathrm { cm }}$

2950 B.C.

Gastropod and lamellibranch shells, water depth $29.70 \mathrm{~m}$.

MC-544. Grotte Huet $26 \mathrm{C}, 280 \mathrm{~cm}$

$5000 \pm 100$

Gastropod and lamellibranch shells, water depth $29.80 \mathrm{~m}$.

\section{MC-545. Grotte Huet 27 C, $300 \mathrm{~cm}$}

$5480 \pm 100$

3530 B.c.

Gastropod and lamellibranch shells, water depth $30 \mathrm{~m}$.

\section{MC-546. Grotte Huet $28 \mathrm{C}, 315 \mathrm{~cm}$}

Gastropod and lamellibranch shells, water depth $30.15 \mathrm{~m}$.

General Comment (H.L.): invasion of Flandrian sea in cave occurred during Preboreal or Boreal. 


\section{Capo Mele series, Ligurian Sea, Italy}

\section{B. Other Countries}

Calcareous organic matter from Core DRA P $10\left(43^{\circ} 55^{\prime} \mathrm{N}\right.$ Lat, $8^{\circ} 14^{\prime}$ E Long) in Ligurian Sea, offshore Capo Mele, water depth $284 \mathrm{~m}$. Coll. and subm. 1968 by C. Vergnaud-Grazzini, Lab. Géol. Dynamique, Fac. Sci., Paris.

\section{MC-249A. Capo Mele 1}

$18,300 \pm 300$

16,350 в.c.

Tests of Madreporeans (Retepora cellulosa) in top of sediment.

\section{MC-249B. Capo Mele 2}

$16,800 \pm 500$

Serpulid tubes from same horizon as MC-249 A. Diluted sample, $48 \%$ inactive gas.

\section{MC-286. Capo Mele 3}

Mixed marine shells, 415 to $420 \mathrm{~cm}$ in core.

MC-288. Capo Mele 4

Lamellibranch shells and serpulid tubes at base of core (depth $>$ $480 \mathrm{~cm})$.

General Comment (C.V.G.): mean paleotemperature of sea surface $\left(+9^{\circ} \mathrm{C}\right)$ recorded on foraminiferal species from whole core, lower $\mathrm{ca} .10^{\circ} \mathrm{C}$ from mean present surface temperature, indicates complete deposit of sediment during cold Würm III and agrees with dates (Vergnaud-Grazzini et al., 1970).

MC-336. Lignano Beach, North Adriatic Sea, Italy

$3200 \pm 90$

1250 в.c.

Marine shells of submerged beach offshore Lignano barrier $\left(45^{\circ} 42^{\prime}\right.$ N Lat, $13^{\circ} 14^{\prime}$ E Long), water depth not $>10 \mathrm{~m}$. May date old coastline. Coll. 1967 and subm. 1969 by A. Stefanon, Ist. Biol. Mare, Venezia, Italy.

\section{Mar Menor series, Murcia, Spain}

Marine shells (mostly Cardium) of Cores M 6, M 45, M 47, M 61, in coastal lake Mar Menor, Prov. Murcia, Spain. Coll. 1969 and subm. 1971 by J. Simonneau, Centre Recherches Séd. Marine, UER Sci. Perpignan, Pyrénées Orientales.

MC-470. Mar Menor M 6, 66 to $119 \mathrm{~cm}$

$3600 \pm 80$

Shells (Cerithium vulgatum) Core M $6\left(37^{\circ} 40^{\prime} 22^{\prime \prime} \mathrm{N}\right.$ Lat, $0^{\circ} 53^{\prime}$ $30^{\prime \prime}$ E Long), 66 to $119 \mathrm{~cm}$ in core.

MC-471. Mar Menor M 45, 20 to $35 \mathrm{~cm} \quad \delta \mathrm{C}^{14 \%} \%=+99 \pm 15$ Shells (Cardium) Core M 45, (37 40' N Lat, $2^{\circ} 56^{\prime} 35^{\prime \prime}$ E Long).

MC-472. Mar Menor M 45, 35 to $55 \mathrm{~cm} \quad \delta \mathrm{C}^{14 \%} \%=+40 \pm 8$ 
MC.473. Mar Menor M 45, 70 to $91 \mathrm{~cm}$

$1420 \pm 80$

MC-474. Mar Menor M 45, 125 to $149 \mathrm{~cm}$ A.D. 530

MC 475. Mar Menor 45,149 to $180 \mathrm{~cm}$

MC-475. Mar Menor M 45, 149 to $180 \mathrm{~cm}$ $2200 \pm 100$ 250 B.c.

MC-476. Mar Menor M 47, 0 to $24 \mathrm{~cm}$ $2700 \pm 100$ 750 в.c.

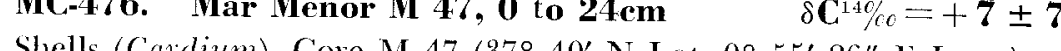

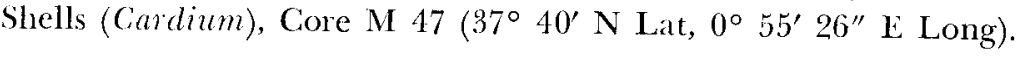

MC-477. Mar Menor M 47, 70 to $90 \mathrm{~cm}$ $635 \pm 60$

MC-478. Mar Menor M 47, 90 to $113 \mathrm{~cm}$ A.D. 1315

MC-480. Mar Menor M 61, 20 to $40 \mathrm{~cm}$ A.D. 1890

$$
2300 \pm 90
$$
350 B.C.

$60 \pm 60$

Shells (Cardium), Core M 61 (37 43 '23" N Lat, $0^{\circ} 53^{\prime} 16^{\prime \prime}$ E Long).

MC-481. Mar Menor M 61, 89 to $147 \mathrm{~cm}$

Mixed marine shells.

$$
1600 \pm 80
$$

MC-363. Bay of Dumbea, New Caledonia A.D. $\mathbf{3 5 0}$

2740 B.C.

$4690 \pm 90$ 2740 B.C.

E Long), water depth $15 \mathrm{~m}$ Bay of Dumbea. Coll 1968 and by J. Launay, ORSTOM, Nouméa, New Caledonia. Comment (J.L.): although sample was cored in hard coral reef surface, beneath $260 \mathrm{~cm}$ of sediment, no conclusion can be drawn about sea level. A mean rate of $50 \mathrm{~cm} /$ millennium can be assessed at the site for accumulation of Dumbea R. sediments (Launay, 1971).

\section{ARCHAEOLOGIC SAMPLES}

A. France

\section{Abri de Saint Mitre No. 3 series, Basses Alpes}

Charcoal from several hearths in No. 3 shelter of Saint Mitre $\left(43^{\circ}\right.$ $53^{\prime} \mathrm{N}$ Lat, $5 \circ 39^{\prime} \mathrm{E}$ Long). Coll. and subm. by A. Calvet, CEA, Cadlarache, Bouches du Rhône.

\section{MC-263. Abri de Saint Mitre No. 3, 1}

$6400 \pm 100$

Layer Y 10, Hearth 3. 4450 в.с.

MC-264. Abri de Saint Mitre No. 3, 2 $6700 \pm 130$

Layer Z 8/9, elliptical Hearth 3: 2xIm covered with $10 \mathrm{~cm}$ thick stone layer. 
MC-265. Alori de Saint Mitre No. 3, 3

Layer Y 11, Hearth 6.

General Comment (A.C.): date, 4000 B.c. (MC-202) for Hearth F 4 in same shelter suggests continuous luman occupation for at least $750 \mathrm{yr}$. Dates agree with Cardial pottery sherds (Calvet and Guilaine, 1970).

\section{Shelter of Font-Juvénal series, Conques, Aude}

Charcoal from archaeologic layers of rich stratigraphic sequence in rock shelter of Font-Juvénal (43 $17^{\prime} 46^{\prime \prime} \mathrm{N}$ Lat, $2^{\circ} 20^{\prime} 54^{\prime \prime} \mathrm{E}$ Long), Conques, Aude. Coll. and subm. 1971 by J. Guilaine, CNRS, Carcassonne, Aude.

MC-490. Font-Juvénal, C 2 b

$4400 \pm 100$

Charcoal from Layer $\mathrm{C} 2 \mathrm{~b}(\mathrm{H} 6, \mathrm{H} 7)$, with Campaniform vases of Pyrenean design.

MC-491. Font-Juvénal, C 3

$4200 \pm 90$ 2250 в.C.

Charcoal from Layer C 3 (H 7). Verazian level, characterized by late Neolithic "pastoral" facies as found in W Languedoc, France.

MC-492. Font-Juvénal C 4

$3620 \pm 90$

1670 в.c.

Charcoal from hearth in Iayer $\mathrm{C} 4(\mathrm{H} 6)$. Verazian level.

MC-493. Font-Juvénal, C 5

$4490 \pm 80$

2540 в.c.

Charcoal from Layer C $5\left(\begin{array}{ll}\mathrm{H} & 7\end{array}\right)$. Two cultural groups present in same layer: Gourgasian (awry point) and Ferrières (incised chcvron adorned pottery).

MC-494. Font-Juvénal, C 12

$4570 \pm 90$

2620 в.с.

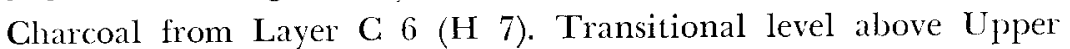
Chassean facies.

MC-495. Font-Juvénal, C 7 a

$4860 \pm 90$

2910 B.C.

Charcoal from Layer C 7 a (H 7). Upper Chassean facies.

MC-496. Font-Juvénal, C 8

$4800 \pm 150$

2850 B.C.

Charcoal from Layer C 8 (H 6). Upper Chassean facies.

MC-497. Font-Juvénal, C 10

$5350 \pm 100$

3400 B.c.

Charcoal from base of Layer C 10 (H 8). Furniture pertains to classical Chassean culture of Languedoc, similar to La Madeleine type: engraved ornaments on plates and clear-silex tools. 
MC-498. Font-Juvénal, C 11

$5540 \pm 100$

Charcoal from hearth in Layer $\mathrm{C} 11$ ( smooth pottery, anterior to typical "Languedocian" facies.

MC-499. Font-Juvénal, C 12

$5850 \pm 100$

Charcoal from Layer C $12(\mathrm{H} 8)$. Epicardial industry antcrior to older Chassean.

General Comment (J.G.): chronologic sequence yields dates for several Languedocian civilizations at site: Chassean, Gourgasian, Ferrières, Vérazian, Campaniform.

\section{B. Italy}

\section{MC-402. Grotte des Enfants, Grimaldi}

$12,200 \pm 400$

Shells (Monodonta turbinata) from burial level of female skeleton, Hearth B, Grotte des linfants (43 $47^{\prime} 00^{\prime \prime} \mathrm{N}$ Lat, $7^{\circ} 32^{\prime} 20^{\prime \prime}$ E Long), Grimaldi, near Vintimiglia, Italy. Coll. by E. Rivière and subm. 1971 by L. Barral, Mus. Anthropol. Monaco. Comment: age agrees with Mesolithic industry and with fauma colder than present (Cervus elaphus, Rangifer tarandus...).

\section{Ksar'Aqil series}

$$
\text { C. Lebanon }
$$

Bones and terrestrial shells from shelter cave of Ksar'Aqil (39 $55^{\circ}$ $\mathrm{N}$ Lat, $35^{\circ} 37^{\prime} \mathrm{E}$ Long) Antelias, $10 \mathrm{~km}$ from Beirut, Lebanon. Coll. 1970 and subm. by J. Tixier, Mus. Hist. Nat., Inst. Paleontol. Humaine, Paris (Braidwood et al., 195I; Tixier, 1970).

\section{MC-411. Ksar'Aqil, I 4, IV.VII}

$14,100 \pm 500$

Bones from Layer C, 350 to $355 \mathrm{~cm}$. Comment: organic fraction. Agrees with relative chronology.

\section{MC-410. Ksar'Aqil, J 8-9, 31, medium}

$24,400 \pm 900$

Terrestrial shells (Helix sp) from Layer $3 \mathrm{~b}, 280$ to $290 \mathrm{~cm}$ Comment: carbonate fraction. Diasagrees with expected date and should be rejected.

\section{Medjez II series, Saint Arnaud, Sétif}

$$
\text { D. Algeria }
$$

Charcoal from large snailery of El Eulma, Sétif, E Algeria $\left(36^{\circ} 08^{\prime}\right.$ $\mathrm{N}$ Lat, $5^{\circ} 40^{\prime} \mathrm{E}$ Long). Continuous stratigraphic layers $365 \mathrm{~cm}$ thick showing evolution of lithic and bone tools throughout more than $2000 \mathrm{yr}$ of Upper Capsian civilization. Coll. and subm. 1969 by G. Camps, LAPEMO, Aix en Provence, France, (Camps et al., 1968).

MC-318. Medjez II, 10, 100 to $125 \mathrm{~cm}$ 
MC-319. Medjez II, 11, 125 to $150 \mathrm{~cm}$

MC-320. Medjez II, 12, 150 to $175 \mathrm{~cm}$

MC-321. Medjez, II, 13, 175 to $200 \mathrm{~cm}$

MC-322. Medjez II, 14, 200 to $225 \mathrm{~cm}$

MC-323. Medjez II, 15, 225 to $250 \mathrm{~cm}$

MC-325. Medjez II, 17, 275 to $300 \mathrm{~cm}$

MC-326. Medjez II, 18, 300 to $325 \mathrm{~cm}$

MC-327. Medjez II, 19, 325 to $350 \mathrm{~cm}$
$7570 \pm 160$ 5620 в.c.

$8230 \pm 130$

6280 в.C.

$7280 \pm 140$

5330 B.c.

$7610 \pm 140$

5660 в.C.

$7280 \pm 120$

5330 в.c.

$7860 \pm 120$

5910 в.c.

$8550 \pm 150$

6600 B.C.

$8860 \pm 150$

6910 B.C.

General Comment (G.C.): complete chronology of site, rich in Microlithic industry, should characterize a regional facies of Upper Capsian: "Setifian." Cf. R., 1972, v. 14, p. 292, (Camps-Fabrer, 1968).

\section{MC-281. Rabah 11, Ouled Djellal, Batna}

$7920 \pm 100$ 5970 B.c.

Terrestrial shells (Helix sp.) from 10 to $20 \mathrm{~cm}$ from terrace bordering Oued Djedi near Ouled Djellal, Batna ( $34^{\circ} 26^{\prime} \mathrm{N}$ Lat, $5^{\circ} 8^{\prime} \mathrm{E}$ Long). Coll. and subm. 1968 by G. Camps.

\section{MC-283. Rahah 4, Ouled Djellal, Batna}

$9180 \pm 130$ 7230 B.C.

Terrestrial shells (Helix) from 30 to $40 \mathrm{~cm}$ in same place as MC-281. Comment: date too old to match this Upper Capsian site.

\section{MC-285. El Mermouta, Ouled Djellal, Batna}

$8410 \pm 130$

Terrestrial shells (Helix) from Neolithic settlement on borcler of Oued Djedi near Ouled Djellal, Batna ( $34^{\circ} 35^{\prime} \mathrm{N}$ Lat, $5^{\circ} 2 \mathrm{I}^{\prime} \mathrm{E}$ Long). Coll. and subm. 1968 by G. Camps. Comment (G.C.): industry is characterized by small and short stone triangles similar to those from Rabah site.

MC-328. Botma si Mamar, Ouled Djellal, Batna

$6880 \pm 100$

Terrestrial shells (Helix) from Neolithic settlement near Ouled Djellal, Batna (34 22' N Lat, 4० 53' E Long). Coll. and subm. 1969 by G. Camps (Grébenart, 1970). 
MC-280. Safiet Bou Rhenan, Messad, Médéa

Tcrrestrial shells (Helix) from Neolithic settlement near Messad, Mécléa (34 $11^{\circ}$ N Lat, $3^{\circ} 31^{\prime}$ E Long). Coll. and subm. 1968 by G. Camps. Comment (G.C.): MC-328 and MC-280 pertain to peculiar Neolithic facies different from Capsian tradition (Grébenart, 1970).

\section{MC-279. Aïn Guettara, Oasis}

$5950 \pm 100$ 4000 B.c.

Charcoal from Neolithic settlement of Capsian tradition, $S$ border of Tademaït Plateau, Oasis (28 $02^{\circ} \mathrm{N}$ Lat, $3^{\circ} 06^{\prime} \mathrm{E}$ Long). Coll. and subm. by G. Camps. Comment (G.G.): agrees with Gif-1223: 3980 B.C., unpub.

\section{MC-399. Bouh Behl, Oasis}

$6290 \pm 120$

Fragments of ostrich eggs in layers of Hadjarian campsite, Bouh Bell, Oasis ( $31^{\circ} 48^{\prime} \mathrm{N}$ Lat, $5^{\circ} 14^{\prime}$ E Long). Lithic industry with geometrical microliths. No pottery. Coll. and subm. 1971 by G. Camps. Comment: agrees with dates from Protoneolithic facies.

\section{MC-400. El Haljar, dismantled, Oasis}

$8050 \pm 100$ $\left(31^{\circ} 2^{2}\right.$ att ( $31^{\circ} 32^{\prime} \mathrm{N}$ Lat, $4^{\circ} 47^{\prime} 30^{\prime \prime} \mathbf{E} \mathrm{Long}$ ). Industry lacking pottery (Hadjarian). Coll. by G. Aumassip and subm. by G. Camps. Cornment (G.C.): date appears very old compared to charcoal from adjoining Epipalaeolithic site (Gif-880: $7900 \pm 170$, R., 1972, v. 14, p. 293) but different stratigraphic position.

\section{MC-398. El Hadjar, Oasis}

$6670 \pm 100$

Fragments of ostrich eags, aceramic Neolithic (all by C. Al.c. and subm. by G. Camps.

\section{MC-401. Khellal, Oasis}

$7750 \pm 100$

Fragments of ostrich eggs in Saharian campsite of Khellal, Oasis $\left(30^{\circ} 31^{\prime} \mathrm{N}\right.$ Lat, $5^{\circ} 53^{\prime} \mathrm{E}$ Long). Coll. by G. Aumassip and subm. 1971 by G. Camps. Comment: only one lithic industry which is poorly typed.

\section{Ahaggar series}

Charcoal from hearths in various sites of Ahaggar arca in Central Sahara (Maitre, 1969). Coll. 1964 to 1967 and subm. by J. P. Maitre, LAPEMO, Aix en Provence, France.

\section{MC-483. Ahaggar, Timidouin, 155-30}

$$
6050 \pm 120
$$

Charcoal, 15 to $30 \mathrm{~cm}$ in 'Timidouin site $\left(24^{\circ} 20^{\prime} \mathrm{N}\right.$ Lat, $5^{\circ} 35^{\prime} \mathrm{E}$ Long), Tefedest, ca. $900 \mathrm{~km} \mathrm{~N}$ Tamanrasset, alt. $1800 \mathrm{~m}$. 
MC-484. Ahaggar, Timidouin, 155-32

$8100 \pm 130$

6150 B.C.

Charcoal, 30 to $60 \mathrm{~cm}$ in same site as MC-483. Comment: dates of MC-483 and MC-484 appear rather old in comparison with ceramics.

MC-485. Ahaggar, Ideles I, 20 to $50 \mathrm{~cm}$

$6050 \pm 100$

Charcoal, 20 to $50 \mathrm{~cm}$ from small cave of Ideles $\left(23^{\circ} 52^{\prime} \mathrm{N}\right.$ Lat, $5^{\circ}$ $55^{\prime}$ E Long) Arcchchoum, $200 \mathrm{~km}$ N NE Tamanrasset, alt. $1450 \mathrm{~m}$.

MC-486. Ahaggar, Ideles, 25 to $40 \mathrm{~cm}$

$5300 \pm 110$

Clarcoal, 25 to $40 \mathrm{~cm}$ in cave of Ideles.

3350 B.C.

\section{MC-488. Ahaggar, Tin Amenser}

$6500 \pm 250$

4550 в.C.

Charcoal, 20 to $70 \mathrm{~cm}$ in Tin Amenser site $\left(22^{\circ} 55^{\prime} \mathrm{N}\right.$ Lat, $5^{\circ} 06^{\prime}$ E Long) Afedafeda, ca. $40 \mathrm{~km} \mathrm{NW}$ Tamanrasset, alt. $1400 \mathrm{~m}$. Comment: further excavation is expected at site.

\section{MC-487. Ahaggar, Tamanrasset II}

$3900 \pm 100$

Charcoal, 45 to $50 \mathrm{~cm}$ level in Tamanrasset site $\left(22^{\circ} 50^{\prime} \mathrm{N}\right.$ Lat, $5^{\circ} 28^{\prime}$ E Long) Oua-Hellerljen, $16 \mathrm{~km}$ NW Tamanrasset, alt. $1470 \mathrm{~m}$. Neolithic industry and remains of Mediterranean flora. Comment: although too young to agree with ceramics and palynology, date compares with Gif357: 3930 B.P. (R., 1970, v. 12, p. 437).

\section{MC-489. Ahaggar, Tadjard Todjdjet}

$4320 \pm 100$

Charcoal, 0 to $20 \mathrm{~cm}$ level in Tadjard Todjeljet site $\left(22^{\circ} 45^{\prime} \mathrm{N}\right.$ Lat, $5^{\circ} 30^{\prime}$ E Long) Oua-Helledjen $5 \mathrm{~km}$ W Tamanrasset, alt. $1350 \mathrm{~m}$. Comment: date confirms late Neolithic as expected.

General Comment: sites dated in Ahaggar Mts. correspond to Neolithic of Sudan tradition which began early 6th millennium and ended late 1000 B.c., with full development during 4th millennium B.c. (Camps et al., 1968).

\section{Aïn Dokkara series, Tebessa}

Terrestrial shells (Helix) and charcoal from "Escargotière du Chacal" a large snail-shell deposit of Ain Dokkara, Tebessa, NE Algeria (35 $20^{\prime}$ N Lat, $8^{\circ} 16^{\prime}$ E Long). Coll. 1968 by C. Roubet and subm. by I. Balout, Inst. Paleontol. Humaine, Paris. I'wo sections dated: 1) Aïn Dokkara S sec., cut 1949, $130 \mathrm{~cm}$ thick, at base of which a human Capsian skeleton was unearthed by L. Balout; 2) Ain Dokkara $\mathrm{N}$ sec. parallel $25 \mathrm{~cm}$ to $\mathrm{N}$ trench of 1951.

$7485 \pm 100$

MC-337. Aïn Dokkara, $S$ sec. 30 to $60 \mathrm{~cm}$ 5535 B.C.

Helix shells, S section 1949, layer 30 to $60 \mathrm{~cm}$. 
MC-338. Aïn Dokkara, $S$ sec. 90 to $110 \mathrm{~cm}$

$7990 \pm 100$

Helix shells.

6040 B.C.

MC-339. Aïn Dokkara, $S$ see. 110 to $130 \mathrm{~cm}$

$8530 \pm 120$

6580 B.C.

MC-340. Aïn Dokkara, $S$ sec., 90 to $120 \mathrm{~cm}$

$7090 \pm 100$

Charcoal.

5140 в.c.

MC-372. Aïn Dokkara N sec., $20 \mathrm{~cm}$

$7260 \pm 120$

5310 в.c.

Helix shells, section parallel $25 \mathrm{~cm} \mathrm{~S}$ to $\mathrm{N}$ trench of 1951 .

MC-373. Aïn Dokkara, N sec., 20 to $40 \mathrm{~cm}$ Helix shells.

MC-374. Aïn Dokkara, $N$ sec., 40 to $60 \mathrm{~cm}$ Helix shells.

MC-375. Aïn Dokkara, N sec., 60 to $80 \mathrm{~cm}$ Holix shells.

MC-376. Aïn Dokkara, N sec., 80 to $100 \mathrm{~cm}$ Helix shells.

General Comment (L.B.): imperceptible evolution of industry through 1300 yr occupation of this typical Capsian site (Balout and Roubet, 1970).

Laang Spean series

$$
\text { E. Cambodia }
$$

Ialang Spean cave $\left(12^{\circ} 51^{\prime} \mathrm{N}\right.$ Lat, $102^{\circ} 55^{\prime} \mathrm{E}$ Long) in Battambang dist., $28 \mathrm{~km}$ from B., Cambodia, a Neolithic settlement dug in Permian limestone. Charcoal from 3 out of 9 principal layers in 2 borings $140 \mathrm{~cm}$ long. Coll. and subm. 1968 by R. and C. Mourer, Univ. Phnom Penh.

\section{MC-270. Laang Spean, CRS}

$1200 \pm 70$

Charcoal from central boring in upper red layer, 2 to $10 \mathrm{~cm}$ with sherds of ornated and shaped stone flakes.

\section{MC-271. Laang Spean, CRa}

$1120 \pm 60$

Charcoal from entrance boring. Upper red layer, 2 to $15 \mathrm{~cm}$.

MC-272. Laang Spean, CRb

$2450 \pm 90$

Charcoal from entrance boring. Red layer, 15 to $30 \mathrm{~cm}$.
500 в.с. 


\section{MC-269. Laang Spean, CRM} with crude industry of hoabinian type, using large tools and atypical stone flakes.

\section{MC-274. Laang Spean CRe}

Charcoal from entrance boring. Lower red layer under $30 \mathrm{~cm}$.

\section{MC-273. Laang Spean, CN}

Charcoal from central boring. Black layer, $30 \mathrm{to} 50 \mathrm{~cm}$ with burnt bones, crude tools and few pottery sherds.

General Comment (C.M., R.M.): uninterrupted occupation of cave from 5 th millennium to 9 th century. Ceramics in black layer dated 4290 B.C. (MC-273) shows that Neolithic in SE Asia is older than formerly supposed (Mourer et al., 1970).

\section{MISCELLANEOUS SAMPLES}

\section{MC-418. Paper}

$$
\mathbf{2 0 0} \pm \mathbf{3 0}
$$

Cloth paper from old Archives dated 1749. Coll. and subm. 1970 by J. Thommeret. Comment: test of accuracy for recent samples.

\section{Atmospheric radiocarbon activity series, Monaco}

This series of $\mathrm{C}^{14}$ content measured in atmospheric $\mathrm{CO}_{2}$ periodically coll. on roof of Mus. Ocćanog. Monaco $\left(43^{\circ} 43^{\prime} \mathrm{N}\right.$ Lat, $7^{\circ} 25^{\prime} \mathrm{E}$ Long) alt. $80 \mathrm{~m}$, is continuation of previous results (R., 1966, v. 8, p. 290-291; R., 1969, v. 11, p. 127-128).

\begin{tabular}{c} 
Sample no. \\
\hline MC-261. \\
MC-310. \\
MC-311. \\
MC-312. \\
MC-313. \\
MC-390. \\
MC-391. \\
MC-392. \\
MC-393. \\
MC-394. \\
MC-395. \\
MC-547. \\
MC-548.
\end{tabular}

\begin{tabular}{ll}
\multicolumn{2}{c}{ Coll. date } \\
\hline Aug. & 1968 \\
Feb. & 1969 \\
May & 1969 \\
Aug. & 1969 \\
Nov. & 1969 \\
April & 1970 \\
Aug. & 1970 \\
Nov. & 1970 \\
March & 1971 \\
July & 1971 \\
Nov. & 1971 \\
April & 1972 \\
Aug. & 1972
\end{tabular}

$$
\begin{gathered}
\delta \mathrm{C}^{1+1 / \%} / \% \\
\hline+593 \pm 15 \\
+507 \pm 15 \\
+512 \pm 15 \\
+502 \pm 15 \\
+502 \pm 15 \\
+550 \pm 15 \\
+590 \pm 15 \\
+500 \pm 15 \\
+515 \pm 15 \\
+490 \pm 10 \\
+542 \pm 10 \\
+480 \pm 10 \\
+500 \pm 10
\end{gathered}
$$




\section{Seawater series} p. 128).

This series continues the list of previous results (R., 1969, v. 11,

\section{MC-267. Seawater $2000 \mathrm{~m}$}

$$
\delta \mathbf{C}^{14 \%} / \omega 0=+\mathbf{2 0} \pm \mathbf{7}
$$

Coll. May 1968, 20km S Monaco.

MC-419. Seawater $1700 \mathrm{~m}$

$\delta \mathbf{C}^{\mathrm{1} 1} / \%=+\mathbf{1 9} \pm \mathbf{7}$

Coll. June 1971, 20km S Monaco.

MC-550. Seawater $2500 \mathrm{~m}$

$$
\delta \mathrm{C}^{11 / \%}=-\mathbf{5 0} \pm \mathbf{1 0}
$$

Coll. June 1972, $30 \mathrm{~km} \mathrm{~S} \mathrm{Monaco.}$

\section{Correction}

In previous list of seawater meatsurements (ibid., above) values given as $\mathrm{C}^{14 \%} \%$ should be $\delta \mathrm{C}^{14 \%} \%$.

\section{RIFLRENCF:}

Balout, L. and Roubet, C., 1970, Datation radiométrique de l'homme Capsien de l'Aïn Dokkara et de son gisement: Lybica, v. 18, p. 23.

Bellaiche, G., 1971, Les dépôts quaternaires immergés du Golfe de Frćjus (Var), comparaison avec d'antres formations quaternaires sous-marines des côtes francaises de la Méditcrance. Nouvelles clomées foumies par les datations au carbone 14: Internatl. sediment. cong. Heidelberg, Nug. 1971.

Bellaiche G. et al., 1969 Paléogéographie quaternaire du Golfe de Fréjus (Var), Etudes sur le quaternaire dans le moncle: 8 th intermatl. INQUA cong. Paris, Aug. 1969, v. 1, p. $165-178$

Blanc, J., Froget, C., and Cien, C., 1967, Géologie littorale et sous-marine dans la région de Marrseille. Relation avec les struclures de la Basse Provence: Gcol. Soc. France Bull., v. 9, p. 561-571.

Bonifay, E., Courtin, J., and Thommeret, J., 1971, Datation des derniers stades de la transgression versilienne clans la région de Marseille: Acad. sci. [Paris] Comptes rendus, v. 273, p. 2042-2044.

Braidwood, R., Wright, H. E., and Ewing, J. F., I951, Ksar'Aqil its archacological sequence and geological sething: Near Eastern studies Jour., v. 10, p. 112-122.

Calvet, A. and Guilaine, J., I970, Nouveaux points de chronologie absolue pour le néolithique ancien de la Méditerranéc occidentale: l'Anthropologie Paris, v. 74 , 110. 1-2, p. $85-92$

Camps, G., Delibrias, G., and Thommerct, J., 1968, Chronologie absolue et successions des civilisations préhistoriques dans le Nord de l'Afrique: Lybica, v, 16, p. $9-28$.

Camps-Iabrer, H., 1968, Le Gisement du Capsien supérieur de Medjez II (El Eulma), département de Sćtif, Algérie: l'Anthropologic, v. 7’s, p. 479-488.

Courtin, J. and Froget, C., 1970, La station néolithique de l'Ile Riou (Sud de Marseille, B. du R.) Etude géologique et archéologique: Mus. Anthropol. préhist. Monaco, Bull., 110. 15, p. I47-157.

Delibrias, G., Guiller, M. T., and Labeyrie, J., 1970, Gif natural radiocarbon measurements V: Radiocarbon, v. 12, p. $421-443$.

1972, Gif: natural radiocarbon measurements VII: Radiocarbon, v. 14, p. $280-320$.

Froget, C., Thommeret, $J$., and Thommeret, Y., 1972, Mollusques septentrionaux en Méditerranée occidentale. Datation par le carbone 14: Palaeogeography, Palacoclimatology, Palacoecology, Amsterdam, v. 12, 110. 4, p. $285-293$.

Grébenart, D., 1970, Problèmes du Néolithique pres d'Ouled Djellal et de Djelfa: Botma si Mamar et Safiet Bou Rhenan: Lybica, v. 18, p. 47-66.

Launay, J., 1971, La sédimentation en Baie de Dumbéa, côte ouest, Nouvelle Calédonie: Pub. ORSIOM, Centre de Nouméa, New Caledonia, p. 1-48. 
Maitre, J. P., 1969, IX mission préhistorique en Ahaggar: Lybica, v. 17, p. 395-402.

Monaco, A., 1971, Contribution à l'étude géologique et sédimentologique du Roussillon (Golfe du Lion): Thesis, Univ. sci. et techn. du Roussillon, Montpellier.

Monaco, A. and Thommeret, J., 1969, Sur l'âge des affleurements rocheux du platcau continental du Roussillon: Acad. sci [Paris] Comptes rendus, v. 268, p. 213-215.

Monaco, A., Thommeret, J., and Thommeret, Y., 1972, L'âge des dépôts quaternaires sur le plateau continental du Roussillon (Golfe du Lion): Acad. sci. [Paris] Comptes rendus, v. 274 , p. 2280.

Mourer, C., Mourer, R., and Thommeret, Y., 1970, Premicres datations absolues de l'habitat préhistorique de la Grotte de Laang Spean, province de Battambang, Cambodge: Acad. sci. [Paris] Comptes rendus, v. 270, p. $471-473$.

Thommeret, J. et al., 1969, Ensemble de comptage et d'impression automatique utilisé pour la datation par la methode du carbone 14: Rept. CEA-R 3702.

Tixier, J., 1970, L'abri sous roche de Ksar'Aqil, Beyrouth (Liban). La campagne de fouilles 1969: Mus. Beyrouth, Bull., v. 23, p. 173-191.

Vergnaud-Grazzini, C. et al., 1970, Note preliminaire à l'étude cles faunes froides immergées du Golfe de Gênes: Cah. Océanog., v. 29, p. 147-154. 